\title{
Pemberdayaan Kader dalam Pemantauan Pertumbuhan dan Perkembangan Balita dengan DDST di Desa Mangliawan Kab. Malang
}

\author{
Nicky Danur Jayanti ${ }^{1}$, Senditya Indah Mayasari ${ }^{2}$ \\ 1,2 Program Studi DIII Kebidanan \\ ${ }^{1,2}$ Sekolah Tinggi Ilmu Kesehatan Widyagama Husada Malang \\ e-mail: ${ }^{1}$ nicky_daanty@yahoo.co.id, ${ }^{2}$ senditya.ap@gmail.com
}

\begin{abstract}
Abstrak
Masa balita adalah masa ketika otak anak berkembang dengan pesat dan cepat dalam menyerap beberapa informasi. Periode emas merupakan periode yang sangat penting dalam suatu siklus perkembangan. DDST merupakan tes yang digunakan untuk memprediksi adanya kelainan pada pertumbuhan dan perkembangan balita. Masa ini merupakan landasan yang menentukan kualitas penerus generasi bangsa. Masa - masa dimana anakmemerlukan perhatian khusus yakni berada pada usia 6-24 bulan, karena pada kelompok umur ini merupakan tahapan perkembangan kritis dan kegagalan tumbuh (growth failure) mulai jelas terlihat. Pengabdian masyarakat in bertujuan untuk meningkatan keterampilan kader Posyandu dalam mengobservasi pertumbuhan dan perkembangan balita juga mampu mengobservasi pertumbuhan dan perkembangan bayi balita secara berkala. Solusi yang ditawarkan oleh tim pelaksana adalah meningkatkan peran dan fungsi kader Posyandu melalui pelatihan tentang metode skrining pemantauan perkembangan anak dengan DDST sekaligus pemantauan langsung terhadap pertumbuhan dan perkembangan pada balita yang berada di desa Mangliawan. Pendampingan pada kader Posyandu selama proses pelaksanaan kegiatan. Monitoring dan evaluasi oleh bidan pelaksana terhadap kader dalam pemantauan tumbuh kembang balita dengan DDST. Rangkaian kegiatan ini dilakukan selama 2 bulan (Juli-September 2018). Kegiatan ini mencapai hasil yakni meningkatnya keterampilan kader Posyandu tentang tumbuh kembang balita sehingga upaya pencegahan, upaya menstimulasi serta upaya penyembuhan dan pemulihan dapat diberikan dengan indikasi atau penyebab yang jelas sedini mungkin pada masa-masa kritis tumbuh kembang. Tersedianya sarana dan prasarana penunjang kegiatan seperti buku panduan, lembar DDST, ATK dan APE. Kader Posyandu telah melaksanakan tugasnya yaitu melakukan Pemantauan tumbuh kembang menggunakan DDST secara berkala.
\end{abstract}

Kata kunci : kader posyandu; tumbuh kembang; DDST

\begin{abstract}
Childhood is a phase when a child's brain develops rapidly and is fast absorbing some information. The golden period is a very important period in the development cycle. DDST is a test used to predict abnormalities in the growth and development of toddlers. This period is the foundation that determines the quality of the successor of the nation's generation. The times when children need special attention are at the age of 6-24 months, because this age group is a critical development and growth failure (growth failure) phase. Community service aims to improve the Posyandu cadre skills in observing the growth and development of toddlers as well as being able to observe the growth and development of toddlers on a regular basis. The solution offered by the implementing team are to improve the role and function of Posyandu cadres through training on the method of screening child development monitoring with DDST as well as direct monitoring of growth and development in children under five in Mangliawan village. Assistance was carried out for Posyandu cadres during the research.Monitoring and evalu. Monitoring and evaluation by implementing midwives are given to the cadres in monitoring toddlers' growth and development with DDST. This study last for 2 months (July-September 2018). The research yielded result, mainly on the increased skill of the Posyandu cadre about toddler growth and development so that prevention, stimulating , healing and recovery efforts can be given with clear indications or causes as early as possible in critical periods of growth and development. Availability of facilities and infrastructure to support activities such as guidebooks, DDST sheet, ATK and APE. Posyandu cadres have carried out their duties, conducting monitoring of growth and development using DDST regularly.
\end{abstract}

Keywords: posyandu cadre; growth; DDST 


\section{PENDAHULUAN}

Pertumbuhan dan perkembangan anak adalah hal yang paling utama dan sangat penting. Mengetahui dan memahami pertumbuhan dan perkembangannya tidak hanya melihat dari satu aspek saja, tetapi ada beberapa hal yang harus diperhatikan yakni nutrisi atau gizi anak, faktor keturunan, kejiwaan, dan proses pembelajaran termasuk didalamnya pendidikan keluarga dan agama. Dalam hal ini perhatian orang tua harus fokus pada pertumbuhan fisik dan stimulasi psikososial. Hal tersebut sangat berperan penting dalam pembentukan perkembangan dan karakter anak. Stimulasi psikososial merupakan perkembangan anak yang ditinjau dari aspek psikososial, bahwa pada masa ini anak dalam perkembangannya dipengaruhi oleh lingkungan sosial [1].

Dari penelitian yang dilakukan [2] pada tes awal, 62 dari 70 anak memiliki indeks perkembangan mental di bawah 70 dilihat dengan Bayley Scales of Infant Development Uji II. Dari 62 anak dalam penilaian tindak lanjut, 30 anak $(48,4 \%)$ masih dalam kisaran kognitif yang sama, 12 anak memiliki fungsi intelektual, 6 ditingkatkan untuk rata-rata fungsi intelektual, dan 5 memiliki gangguan bahasa tertentu, 9 memiliki gangguan spektrum autisme. Ikatan Dokter Anak Indonesia (IDAI) Jawa timur (2007), melakukan pemeriksaan terhadap 2.634 anak, hasil deteksi pertumbuhan dari berat badan yakni sebanyak 14,3\% mengalami gizi kurang, gizi baik $82,1 \%$ dan gizi lebih mencapai 3,6\%. Sedangkan tinggi badan, kategori perawakan pendek $13,8 \%$, tinggi badan normal sesuai usia mencapai $83,3 \%$ dan perawakan tinggi 2,9\%. Lingkar kepala ditemukan microcephaly atau kepala lebih kecil dari usia normal sekitar 8,3\%, normal $90,0 \%$ dan makrochephaly hanya $1,7 \%$. Sementara untuk perkembangan normal sesuai dengan usia 53\%, meragukan sekitar $13 \%$, penyimpangan perkembangan mancapai angka $34 \%$. Dari penyimpangan perkembangan, $10 \%$ pada motorik kasar (seperti berjalan, duduk dan lain-lain), 30\% motorik halus (seperti menulis, memegang dan lain-lain), 44\% pada bicara bahasa dan $16 \%$ tentang sosialisasi kemandirian.

Agar perkembangan individu optimal, maka diperlukan pemberian rangsangan atau stimulasi sesuai dengan tahapan perkembangannya karena jika tidak atau kurang pada proses stimulasi dapat menyebabkan penyimpangan tumbuh kembang anak bahkan gangguan menetap [4]. Menurut hasil riset perkembangan kognitif terendah ditemukan pada anak dengan stimulasi psikososial yang buruk, sedangkan anak dengan stimulasi psikososial yang tinggi makantinggi pula nilai perkembangan kognitifnya. Dengan demikian dapat disimpulkan stimulasi psikososial berkorelasi secara signifikan dengan perkembangan kognitif anak [3]. Dalam hal pemantauan tumbuh kembang balita peran tenaga kesehatan dan kader kesehatan yang hangat, membantu, serta turut berpartisipasi akan lebih menjamin keberhasilan deteksi penyimpangan pada tumbuh kembang balita.

Untuk menggambarkan situasi dari mitra Pengabdian Kepada Masyarakat, tim pelaksana melakukan survey melalui bidan koordinator wilayah Desa Mangliawan Kec. Pakis, didapatkan data bahwa sebagian besar kader posyandu pernah mendapatkan penyuluhan tentang cara pemeriksaan tumbuh kembang balita menggunakan DDST, tetapi belum di terapkan secara maksimal.

\section{SUMBER INSIPRASI}

Berikut uraian tentang permasalahan atau kebutuhan mitra yang disipekati bersama untuk diselesaikan atau tantangan pokok yang menjadi target kegiatan: 1) Kurangnya pengetahuan dan keterampilan kader Posyandu dalam pemantauan tumbuh kembang pada balita, 2) Banyaknya balita yang tidak dipantau tumbuh kembangnya secara rutin atau berkala, 3) Monitoring dan evaluasi yang belum optimal oleh bidan desa, 4) Terbatasnya sarana dan prasarana dalam pemantauan pertumbuhan dan perkembangan. Hal tersebut menunjukkan masih banyaknya tantangan 
Pemberdayaan Kader dalam Pemantauan Pertumbuhan dan Perkembangan Balita dengan DDST

dalam pelaksanaan Pengabdian Kepada Masyarakat Program "Pemberdayaan Kader Kesehatan dalam Pemantauan Pertumbuhan dan Perkembangan Balita di Desa Mangliawan Kec. Pakis", oleh karena itu pembinaan pada mitra Pembinaan pada mitra Pengadian Kepada Masyarakat perlu dilaksanakan.

\section{METODE KEGIATAN}

Metode pelaksanaan Pengabdian kepada masyarakat program Pemberdayaan Kader dalam Pemantauan Tumbuh Kembang Balita adalah sebagai berikut: 1) Penyuluhan/ Pendidikan kesehatan kepada kader Posyandu tentang Tumbuh Kembang Balita, 2) TOT (Training of Trainer), melakukan pelatihan kepada kader Posyandu tentang Pemantauan dan Pemberian Stimulasi Perkembang Balita, dan 3) Evaluasi dan monitoring dalam bentuk konsultasi tentang pelaksanaan pemeriksaan tumbuh kembang dengan menggunakan DDST oleh kader Posyandu

\section{KARYA UTAMA}

Karya utama dalam pengabdian ini berupa modul Panduan DDST dan lembar DDST yang berukuran besar yang di distribusikan pada tiap Pos Posyandu. Karya ini secara khusus disusun untuk mempermudah kader Posyandu dalam melakukan pemantauan tumbuh kembang pada bayi dan balita. Modul tersebut diberikan dan disampaikan pada saat dilakukan pelatihan pada kader Posyandu dan pembagian lembar DDST raksasa di akhir pelatihan. Selain modul, kader Posyandu juga diberikan lefleat tentang pertumbuhan dan perkembangan pada bayi dan balita.

\section{ULASAN KARYA}

\section{Kegiatan Pelatihan Pemantauan Tumbuh Kembang}

Proses persiapan dilakukan sejak awal bulan Juli 2018 melalui koordinasi antara tim pengusul bersama mitra. Tahap persiapan oleh tim pengabdi dilakukan melalui koordinasi internal tim. Proses koordinasi internal tim dilakukan beberapa kali dimana fokus kegiatan adalah pada pembagian jobdescription masing- masing anggota, pembahasan teknis kegiatan serta diskusi terkait media pembelajaran yang akan digunakan (panduan, SOP, video, dll). Hasil diskusi tim menyepakati bahwa materi pelatihan DDST akan diberikan oleh ketua tim, dengan mahasiswa sebagai fasilitator.

Berkas kegiatan yang disiapkan oleh tim antara lain: materi pelatihan, pelatihan kit, absensi peserta, berita acara kegiatan dan lain-lain. Persiapan tempat kegiatan serta sarana prasarana penunjang dilakukan bersama mitra. Hasil koordinasi menyepakati bahwa kegiatan akan diselenggarakan di Balai Desa Mangliawan. Sarana penunjang seperti meja dan kursi dibantu oleh pihak mitra menggunakan sarana prasarana inventaris Balai Desa Mangliawan.

Tahapan inti ada dua kegiatan yakni penyuluhan tentang Pertumbuhan dan Perkembangan Balita serta Pelatihan tentang Pemantauan Perkembangan dengan DDST dilaksanakan pada hari Senin, 20 Agustus 2018 bertempat di Balai Desa Mangliawan. Kegiatan berlangsung mulai pukul 08.30 hingga $13.30 \mathrm{WIB}$.

Total peserta pelatihan dari Kader Posyandu Balita terdiri dari 37 orang. Persentase kehadiran 74\% dari jumlah keseluruhan Kader Posyandu Balita. Materi utama yang disampaikan dalam kegiatan pelatihan kader ini adalah: Pemantauan tumbuh kembang dengan menggunakan DDST.

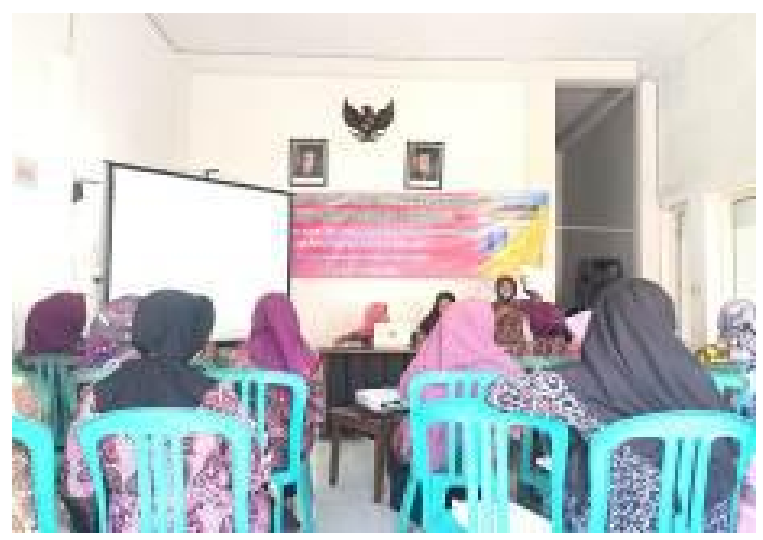

Gambar 1. Penyajian Materi Oleh Tim Pengabdi Bersama Mitra 
Pada sesi materi peserta mendapatkan penjelasan mengenai konsep dan indikator pertumbuhan dan perkembang dan materi DDST. Peserta diperkenankan mengajukan pertanyaan jika selama proses penyampaian materi dirasa terdapat hal-hal yang kurang dipahami. Demo pengisian lembar DDST juga dilakukan bersamaan dengan penyampaian materi untuk memberikan gambaran secara menyeluruh kepada peserta. Peserta diberikan contoh kasus untuk didiskusikan bersama kelompok kecil yang selanjutnya dituangkan dalam lembar DDST.

Beberapa keuntungan dan kerugian penggunaan DDST ini adalah aspek yang dinilai cukup banyak sehingga dalam pengisian lembar DDST memerlukan konsentrasi yang mendalam, ketelitian serta memerlukan latihan sesering mungkin untuk mencapai hasil yang sesuai. Kelebihannya adalah hasil pemeriksaan langsung mengacu pada beberapa sektor yang mengalami gangguan, baik itu motorik halus, motorik kasar maupun bahasa. Alternatif lain dalam pemeriksaan tumbuh kembang adalah KPSP, KPSP lebih mudah dalam pengisiannya hanya menjawab pertanyaan - pertanyaan yang ada di lembar KPSP. Kerugiaannya adalah hambatan perkembangan tidak dapat langsung terdeteksi apakah motorik halus, motorik kasar atau bahasa yang terhambat.

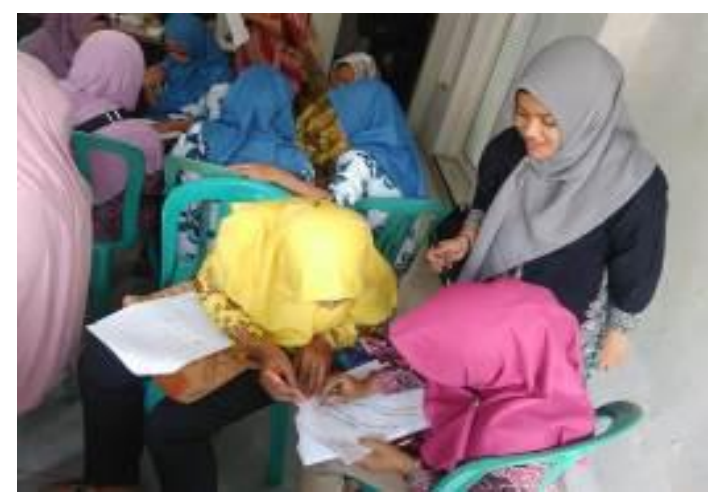

Gambar 2. Praktik pengisian lembar DDST oleh Kader Posyandu

Kegiatan diskusi kelompok diakhiri dengan review materi dan kesimpulan dalam kelompok-kelompok kecil. Kelompok-kelompok kecil kemudian dibubarkan dan peserta kembali ke tempat duduk semula. Pembagian kuisioner dilakukan untuk mengevaluasi tingkat pemahaman peserta terhadap materi pelatihan pada akhir sesi. Peserta yang mampu menjawab pertanyaan tim pengabdi dengan baik akan mendapatkan doorprize.

Tim pengabdi melakukan evaluasi paska kegiatan pelatihan mencakup jumlah kehadiran peserta, peran mitra dalam kegiatan, keaktifan peserta, pemateri dan proses penyampaian materi, sarana prasarana, serta kinerja tim.

Peserta kembali ke tempat duduk semula. Pembagian kuisioner dilakukan untuk mengevaluasi tingkat pemahaman peserta terhadap materi pelatihan pada akhir sesi. Peserta yang mampu menjawab pertanyaan tim pengabdi dengan baik akan mendapatkan doorprize.

Tim pengabdi melakukan evaluasi paska kegiatan pelatihan mencakup jumlah kehadiran peserta, peran mitra dalam kegiatan, keaktifan peserta, pemateri dan proses penyampaian materi, sarana prasarana, serta kinerja tim.

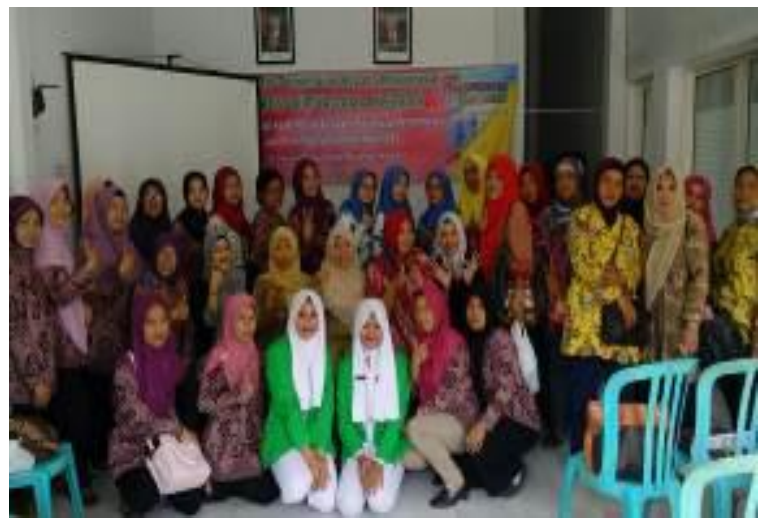

Gambar 3. Foto Bersama Bidan Desa dan Kader Posyandu

\section{Monitoring dan Evaluasi Pelaksanaan serta rencana tindak lanjut pemecahan masalah}

Evaluasi pelaksaanaan Pengabdian Kepada Masyarakat dilakukan dengan tujuan untuk mengetahui kesulitan/kekurangan yang timbul selama kegiatan tersebut dilakukan, disamping evaliasi dilakukan kegiatan monitoring. Monitoring dilakukan bertujuan untuk mengetahui sejauh mana penyerapan penyuluhan 
dan pelatihan tersebut serta upaya pendampingan dalam melaksanakan pengabdian ini.

Salah satu bentuk kegiatan yang diusulkan oleh peserta pada saat evaluasi untuk keberlanjutan yakni menggunakan media komunikasi seperti SMS (short message service) atau atau WA (whats app) untuk memfasilitasi komunikasi dan diskusi serta dibentuknya self help group sebagai wadah untuk membantu/ memberikan dukungan/berbagi pengalaman bagi kader.

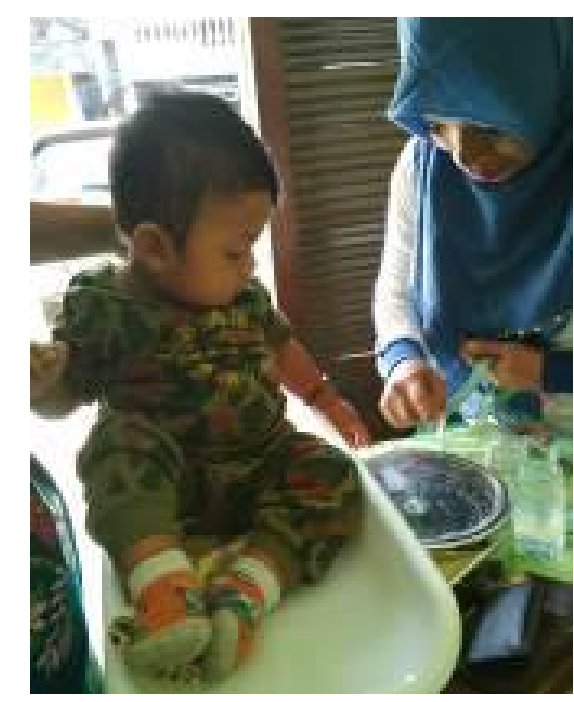

Gambar 4. Evaluasi Kader Posyandu dalam Pemantauan Pertumbuhan dan Perkembangan

\section{KESIMPULAN}

Kegiatan Pengabdian Kepada Masyarakat yang telah dilakukan oleh Tim Pengabdi dapat menjadi solusi bagi kader Posyandu Desa Mangliawan Kec. Pakis dalam upaya peningkatan pemantauan tumbuh kembang bayi dan balita. Capaian kegiatan yang telah dilakukan antara lain: 1) Kader Posyandu menguasai teori konsep dan indikator pertumbuhan dan perkembangan, 2) Kader Posyandu menguasai konsep teori dan praktik pemantauan tumbuh kembang menggunakan DDST, 3) Tersedianya sarana dan prasarana penunjang kegiatan seperti buku panduan, lembar DDST, ATK dan APE, dan 4) Kader telah melakukan tugasnya yaitu melakukan pemantauan tumbuh kembang bayi dan balita sesuai jadwal Posyandu.

\section{DAMPAK DAN MANFAAT KEGIATAN}

Dampak dan manfaat dari kegiatan pengabdian ini antara lain peningkatan kegiatan edukasi, sosialisasi dan advokasi terkait pemeriksaan tumbuh kembang dengan DDST oleh instansi terkait dibantu oleh kader posyandu dan masyarakat sehingga meningkatkan pengetahuan dan motivasi masyarakat dalam memantau tumbuh kembang anak. Dengan meningkatnya pengetahuan dan keterampilan kader posyandu tentang pemantauan tumbuh kembang dengan DDST dapat menekan angka morbiditas pada bayi, peningkatan kesehatan serta kesejahteraan ibu dan bayi di Desa Mangliawan Kabupaten Malang.

\section{DAFTAR PUSTAKA}

[1] Hidayat, A.A. (2011). Ilmu Kesehatan Anak untuk Pendidikan Bidan. Jakarta : Salemba Medika.

[2] Jeong Ji Eun, et.al. 2014. Developmental Profiles of Preschool Children with Delayed Language Development. Korean J Pediatri 2014;57 (8): 363369.

[3] Lauren, S. 2011. Ensiklopedia Perkembangan Anak, alih bahasa Lukman Andrian dan Cahyani Insanwati. Jakarta: Erlangga.

[4] Soetjiningsih. 2012. Tumbuh Kembang Anak. Jakarta: EGC. 